(c) EUSP, 2017 ej $\quad$ ISSN 2310-3817 Vol.5 SU'SIS No.2(engl) p. 136-163

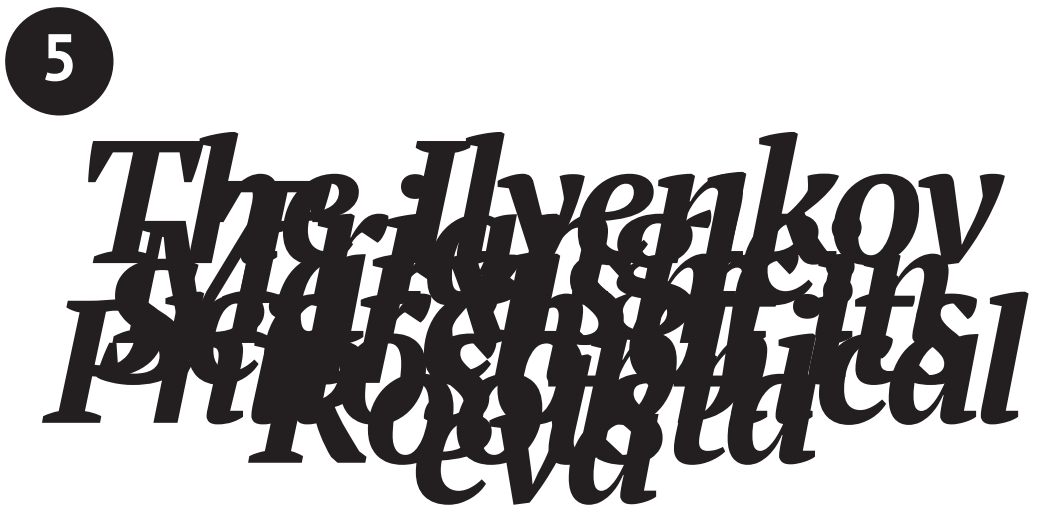

\title{
Andrey Maidansky
}

Belgorod State University,

Institute of Philosophy, Russian Academy of Sciences

\section{The Ilyenkov Triangle: Marxism in Search of its Philosophical Roots ${ }^{1}$}

\begin{abstract}
Studying the phenomena of the ideal, Evald Ilyenkov checks every important step in his thinking with Hegel and Spinoza. Their philosophical teachings form the foundation for the triangle of "dialectical logic," at the peak of which is Marx with his method of "ascending to the concrete." This work will carry out a comparison of the conceptions of Ilyenkov and Western European Marxists along the "Hegel-Spinoza" line.
\end{abstract}

Keywords

Evald Ilyenkov, Marx, Spinoza, Hegel, Marxism, dialectics, dialectical logic, method of knowledge, ascending from the abstract to the concrete

The research is supported by the Russian Foundation for the Humanities (RGNF), grant No. 17-03-00160a. 
Marxism started from the revolt against the philosophy of Hegel that had nurtured it. In Brussels in 1845, Karl Marx and Friedrich Engels decided to finally settle accounts with their "former philosophical conscience" (Marx 1987: 263). Henceforth, an actual "science of history" must occupy the place of "philosophical phrases" concerning reality. The time of philosophizing was past..."When reality is depicted, philosophy as an independent branch of knowledge loses its medium of existence" (Marx and Engels 1976: 35). "[W]hen we conceive things thus, as they really are and happened, every profound philosophical problem is resolved [...] quite simply into an empirical fact" (Marx and Engels 1976: 58).

Having set about the scientific investigation of reality-"empirical facts" in their logical and historical links-Marx stopped calling his views "philosophy." Henceforth, in philosophy (side by side with "legal, political, religious-in short, ideological forms") he sees only a distorted reflection of economic relations turned on its head-spiritual "sublimations" of the material existence of people.

This does not mean, however, that philosophy can be written off as salvage. To its daughters, the "positive sciences," it has left the legacy of the logical method of thinking: the dialectic. Marx drew this lesson from reading Hegel. "[M]etaphysics-indeed all philosophy-can be summed up, according to Hegel, in method" (Marx 1976: 161). Cleansed of idealistic mysticism, the dialectical method is of no small help to the scientist in their work. Marx assured himself of this in his own experience.

What was of great use to me as regards method of treatment was Hegel's Logic at which I had taken another look at by mere accident [...] I should very much like to write two or three sheets making accessible to the common reader the rational aspect of the method which Hegel not only discovered but also mystified (Marx 1983: 249).

A couple of unwritten sheets about the dialectical method-this is the entire "philosophy of Marx." There is no trace of any other philosophy in his mature works. If philosophy is to be understood according to Marx...

Very quickly-even before the end of the nineteenth century-Plekhanov and his students were inventing Marxist philosophy as a "general synthetic view of nature and life" (Plekhanov 1928: 324). Subsequently, drawing a philosophical map of the world in the manner of Comte and Dühring became the favourite pursuit of the Soviet "diamat" (the scholastic version of dialectical materialism).

The material for the construction of a "Marxist philosophy" was found in the works of the young Marx, from his doctoral dissertation to the 
theses on Feuerbach. However, it was mainly the problem of man that interested Marx; the problems of metaphysics, which form the foundation of classical philosophy, are almost absent in his works. Philosophically preoccupied Marxists began to fill in this metaphysical gap with fashionable contemporary concepts drawn from the neo-Kantians and positivists.

In response, Jakob Stern called upon Marxists to rely on the metaphysics of Spinoza, and Plekhanov enthusiastically supported this suggestion (Stern 1897; Plekhanov 1956: 351). Thus, the vector for construction of a Marxist philosophy was given, on which Abram Deborin and his school-and, after World War II, Evald Ilyenkov and the Western Marxists surrounding Louis Althusser-oriented themselves.

On the other side, V. I. Lenin, Georg Lukács, Antonio Gramsci and many others practically ignored Spinoza, preferring the path recommended by Marx and the trail blazed by Engels of the materialist treatment of Hegel's logic. After all, Marx never counted Spinoza among his predecessors alongside Hegel and Ricardo. On the contrary, in The Holy Family, he fervently hailed the criticism that sensualists Pierre Bayle and Étienne Bonnot de Condillac rained down on Spinoza. They mention the name of Spinoza among seventeenth-century metaphysicians "driven from the field by the French Enlightenment" (Marx and Engels 1975: 125). Marx slighted Spinoza's substance as "metaphysically disguised nature separated from man" (Marx and Engels 1975: 139). ${ }^{2}$ Plekhanov and Ilyenkov preferred not to recall this devastating assessment.

Spinozism is sublated dialectically in the philosophy of Hegel-converted into its "first element" alongside "Fichte's self-consciousness," Marx maintained. With that kind of bilious contempt, he spoke of the backwards movement of thought from Hegelian logic to Spinozist metaphysics in David Strauss - and how he applauded Feuerbach, having broken once and for all with the "drunken speculation" of the metaphysicians!

The further movement of philosophical thought could only be antimetaphysical-returning to man everything that was taken from him by metaphysics on behalf of the "Absolute Spirit," of deified "Nature," or of abstract "substance." Along this humanistic road, in the field of positive science concerning man-away from any metaphysics!-the thought of Feuerbach moved. In his person, "materialism, coinciding with humanism" (Humanismus zusammenfallenden Materialismus) put an end to metaphysics - the young Marx did not spare the italics in singing the praises of his hero.

Feuerbach, who completed and criticised Hegel from Hegel's point of view by resolving the metaphysical Absolute Spirit into "real man on the basis

2 "Die metaphysisch travestierte Natur in der Trennung vom Menschen" (Marx 1962: 147). 
of nature," was the first to complete the criticism of religion by sketching in a grand and masterly manner the basic features of the criticism of Hegel's speculation and hence of all metaphysics (Marx and Engels 1975: $139)$.

Scientific materialism must look in the face of "real life," and not look back in search of metaphysical bearings. This is probably how Marx would have answered his prodigal children, the philosophizing Marxistsboth the ones who looked back at Kant (Konrad Schmidt, Eduard Bernstein) and those who intended to transplant the tree of Marxism onto the soil of Spinoza's metaphysics.

Engels treated Spinoza much more benevolently. Unlike his friend and co-author, he considered Spinoza a "brilliant exponent" of dialectics (Engels 1987: 21), joining the ranks with Hegel against the "metaphysical mode of thought" in which English empiricists and French Enlighteners were "stuck." Engels acknowledges in Spinoza the "highest credit" of "explaining the world from the world itself"-in contrast to the mechanistic knowledge of nature of the time (Engels 1987: 323).

In Engels, Plekhanov's philosophical strivings met with sympathy and support. In a personal meeting in 1889, Plekhanov was curious: Was it possible to consider the Spinozist solution to the "great fundamental question" of philosophy-the problem of the relation of thought and matter-correct? And Engels, in the presence of two witnesses, acknowledged the correctness of "old Spinoza." Inspired, Plekhanov proclaimed Spinoza the direct predecessor of Marxism in the field of philosophy. With that, Spinoza was automatically enrolled in the camp of materialists, although with a reservation regarding the birthmarks of theology on his brow.

Against the background of the professional studies of Spinoza begun at that time (Jacob Freudenthal, Koenraad Meinsma, and others; in Russia a little later-Lev Robinson and Varvara Polovtsova), Plekhanov's reading appears simply primitive. The Ethics seemed beyond his capacity, and he portrayed Spinoza himself as a prototype of Diderot and Feuerbach clothed in "theological attire" (calling nature "God" is unbecoming of a respectable materialist). Around this awkward figure-an atheist in theologists' clothing-the ideological passions of the 1920s flare up. ${ }^{3}$

Meanwhile, new facets and depths were discovered in Spinoza's philosophy-ones that the readers of past centuries never dreamed of. Three centuries later, it found new breath. The best Marxist minds did not remain on the side. They interpreted Spinoza's Ethics as their Old Testament and began re-reading it anew through Marx's methodological "eyeglasses."

3 For more detail on this, see Maidansky (2012). 
In the works of Spinoza, Ilyenkov and Althusser discover not proMarxist metaphysics, nor a "synthetic view" of the world, but a logic of a new type: a principle of the relation of thought to reality and a method of theoretical cognition that anticipated the materialist dialectic of Marx. Above all, both Ilyenkov and Althusser appreciate in Spinoza the striving to think concretely ${ }^{4}$ and both criticize Hegel for the "mystification" of the relation between the abstract and the concrete, between the ideal and the real. But if Althusser sought an antidote to Hegelian dialectics in the texts of Spinoza, Ilyenkov enters the name of Spinoza into the history of dialectical logic, ranking him with Hegel and Marx.

The point was not about the direct influence of Spinoza on Marx. Althusser acknowledges that Marx only knew Spinoza's works poorly, but it is precisely thanks to Marx that the possibility of properly understanding Spinoza's thought was discovered. ${ }^{5}$ Ilyenkov would certainly have agreed with the latter. Both philosophers came to Spinoza late enoughonly in the 1960s, with many years of experience reading Marx behind them.

We will see how the continuity of the dialectical logic of Marx in relation to the teachings of Hegel and Spinoza appears to Ilyenkov, and we will compare his solution with the interpretations of the philosophical roots of Marxism in the schools of Della Volpe and Althusser. Such a reflection will provide a "binocular" vision, so to speak, of the problem and will be useful for a critical correction of each of the positions.

\section{II}

To trace his philosophical triangle, Ilyenkov began with the line "Hegel-Marx."Theaccusation of"harmfulHegelianism"(gegel'janshchina) followed him throughout his life. In philosophy, Ilyenkov saw nothing other than Logic (he loved capitalizing the word), and only that. He made one reservation, however: Hegel's mistake in passing off "the fact of logic" as "the logic of fact"-that is, substituting a philosophical and logical schema for a concrete scientific investigation of a subject existing independently of thought-should not be repeated. It is this exact sin that the

4 Spinoza demands this with complete straightforwardness: "[I]t is [...] necessary for us to deduce all our ideas from things physical or from real entities, by advancing as strictly as possible according to the sequence of causes from one real entity to another real entity, and not passing over to abstracts and universals, neither for the sake of deducing anything real from them, nor of deducing them from anything real" (Spinoza 1925b: 36).

“...History buried [Spinoza] in impenetrable darkness. Only through Marx, who, however, had little knowledge of him (qui pourtant le conassait mal), do we even begin to guess at the features of that trampled face (les traits de ce visage piétiné)" (Althusser 1969: 63). 
young Ilyenkov accused official Diamat of, in the figure of Teodor Oizerman, his supervisor of studies.

Now [let us take] Oizerman's conception. This is a Hegelian interpretation. Philosophy as "world outlook," understood as a detailed system of abstract definitions of method. Whereas method may be detailed only in one system-the system of positive knowledge-and only in this form does it have the significance of a world outlook. It exists only in its application (Ilyenkov 2016: 216).

As we can see, Ilyenkov re-addresses the critical accusation of "harmful Hegelianism" towards his adversaries, who regard philosophy as a "world outlook"-a map of the world as a whole, in contrast to the "concrete sciences" occupied with the investigation of some individual "layers" of reality. Any science, philosophy included, must outline a concrete sphere of phenomena being investigated and must stand firm within the boundaries of its subject, as Ilyenkov admonished.

Narrowing the subject of philosophy to the "field of thought," ${ }^{\prime \prime}$ transforming philosophy into a study of the method of theoretical knowledgeinto the science of Logic-constitutes Hegel's historical contribution. With that, however, the "field of thought" itself is expanded to the world as $a$ whole, and so at the outlet Hegel receives, yet again, a philosophical "world outlook"-metaphysics. The dialectical method, discovered by him, is developed not into a concrete scientific theory, or "system of positive knowledge," as Ilyenkov expresses himself, but into a "speculative" map of the world.

Hegel [...] broadened [the subject of philosophy] to universal limits, and tried to solve the questions of positive knowledge beyond the sciences and despite them; the reactionary side of his philosophy is exactly in this [...] And where Hegel took up natural philosophy, the philosophy of historythere he piled up schemas and constructions that had no significance for the real development of philosophy (Ilyenkov 2016: 210-11).

Marx acted otherwise. Before applying the dialectical method for the "treatment of material" in the field of political economy, he collected material for years-studying the actual history of world economics and the works of his predecessors. In turning into an economist, Marx the philosopher mastered a second profession. Dialectical logic served him as a

6 From the shorthand report of the legendary speech by the dean of Moscow State University, Vasilij Molodcov: “'The theses of Comrades Korovikov and Ilyenkov pull us into the field of thinking.' [Laughter in the hall.] 'Don't worry, there is no means to pull you there!'-shouted from the hall” (Ilyenkov and Korovikov 2016a: 59). 
compass and a reference point in this enterprise, and not as a master key to any lock in economics.

Dialectics aims the mind at the search for opposing forces, sides, and processes in the moment of the mutual transformation of opposites-abstract and concrete labor, living labor and reified labor (labor power and capital), the relative and the equivalent forms of value, and so on-but does not provide formulae for the solution of concrete scientific problems. A concrete analysis of the facts is required for their solution, accompanied by criticism of previously created concepts and theories in the given subject field.

The only field in which the dialectical method is self-sufficient is the "kingdom of pure thought," that is the specific problem of The Science of Logic. Hegel is great, where he investigates the world of spiritual culturethe phenomena of the ideal. When he gets down to material things, his dialectic immediately reverts to typical metaphysics.

The same thing occurs with every other science when it goes beyond the framework of its scope and loses its concrete subject. Thus, having threatened physicists with metaphysics, Newton time and again fell into a metaphysics of the worst sort, half-and-half with theology. The physiology of higher nervous activity-in the person of Ivan Pavlov-attempted to solve the problems of psychology; cybernetics tried to construct a model of thinking, "artificial intelligence," without having the slightest correct idea of nature and logical structure of thinking-of "natural intelligence," as it were.

Throughout his life, Ilyenkov came out against the "metaphysical" adventures of philosophers and mathematicians, physiologists and geneticists, cyberneticians and linguists - he called for and demanded thinking concretely. This antimetaphysical tenet of Ilyenkov's dialectical logic was met with support among the Italian Marxists of the school of Galvano Della Volpe. The latter exposed the interpretation of dialectics as a philosophical "theory of everything"-a general map of the world based on the three laws of dialectics (as a variant, on the "four features" of the dialectic, in Stalin)-to criticism a decade earlier than Althusser.

Della Volpe named Hegel as the main culprit of this philosophical mystification, and in the search for alternate predecessors of Marx's Capital patriotically pointed out his fellow countryman Galileo. His student

"Accordingly, logic is to be understood as the system of pure reason, as the realm of pure thought (das Reich des reinen Gedankens)" (Hegel 1970: 103). Engels borrowed this phrase verbatim for a description of what remains to the lot of philosophy after its banishment from nature and the history by the "positive sciences'." The investigation of the laws of thinking-formal logic and the dialectical method-this is all that philosophers can usefully devote themselves to for the business. All the other “philosophical baggage," in Engels's opinion, became useless for the scientific understanding of reality (see Engels 1990: 396-97). 
Lucio Colletti was not so eccentric, having displayed a preference for Kant. Marx simply did not realize how indebted he was to Kantian "criticism"; it was not for nothing that both Marx and Kant adored putting the word "critique" in the titles of their books...

Colletti wrote the foreword to the Italian edition of Ilyenkov's first book-on the method of Marx's Capital. ${ }^{8}$ In this field, the Italian Marxists by rights considered themselves pioneers and, naturally, hailed the appearance of a kindred spirit in the Soviet Union. Only Ilyenkov's love for Hegel did not make them happy.

The section dedicated to criticism of Hegel does not seem particularly clear and deep, although here Ilyenkov proves to be one of the least "Hegelian" among present-day Soviet dialectical materialists, and one of those (which is not a paradox) who demonstrates first-hand knowledge of the Greater Logic (Colletti 1961: LVII-LVIII).

Della Volpe and Colletti believed the mark of "Hegelianism" to be conclusions on the basis of undefined, general (generiche) abstractions that do not grasp the specific character of the subject. In their time, medieval scholastics explained the world by entering observed facts into a metaphysical (Biblical and Aristotelian) map of the world. Galileo smashed this speculative tradition, having counted on the facts of experience-on singularity and multiplicity (singolarità e molteplicità) - and Marx did exactly the same thing, having repudiated the idealistic scholasticism of Hegel.

In his book Logica come scienza positiva (1950), ${ }^{9}$ Della Volpe opposed Marx's determinate or historical abstractions (astrazioni determinate $o$ storiche)-labor, commodities, money, and capital-to the undefined, general abstractions of Hegelian logic. Each of them expresses relationships that are inherent in different forms of society, but acquire universality and become "practically true" only in modern bourgeois society. These abstractions express the specific character of the bourgeois economic formation. In Della Volpe's opinion, Galileo used the same sort of "determinate abstractions.”

In Ilyenkov, the concept of "concrete abstraction" as a unity of opposites-the abstract and the concrete-or as a "universal (vseobshchee), containing all the riches of the particular and the individual" ${ }^{10}$ corresponds to

8 See Ilyenkov (1960). This was a remade and significantly abridged version of the 1956 manuscript, published only at the close of the twentieth century (Ilyenkov 1997a).

The second, posthumous edition of the book came out under the title Logico come scienza storica (1969).

10 Ilyenkov frequently cited this formula from Lenin's Philosophical Notebooks (see Lenin 1973: 90). 
this. A simple, formal abstraction only records the similarities of things, their general properties; a concrete abstraction shows the specific link of individual things, phenomena, as the elements of a unified whole.

If abstraction as such reflects the individual thing (phenomenon, fact, object, and so on) only from the side from which it - the thing-is similar and identical to an entire number of other such things, then, on the contrary, a concrete abstraction reflects exactly the specific nature of the particular or individual phenomenon being examined (Ilyenkov 1997a: 157).

For all the obvious similarity in the conception of abstraction in Della Volpe and Ilyenkov (and in Colletti, we meet the term "concrete abstraction" itself), there are important differences. For Ilyenkov, any concept, in the true sense of the word, is concrete. The abstraction that singles out the similar features of phenomena is not a concept (Begriff) but only a representation (Vorstellung), Ilyenkov asserts. Not only do Galileo and Marx think concretely; so does any normal scientist-and every person, in general-who understands the causes of events and acts rationally, according to the logic of things.

The philosophical thought of Hegel is concrete to the extent that it is occupied with the proper "fact of logic"-the elucidation of the dialectical interrelationship of its "own" categories: being, essence and concept, quantity, quality and measure, cause and effect, the necessary and the accidental, and so on. Hegel succeeded in carrying out the greatest revolution in the history of this science since the time of Aristotle. ${ }^{11}$

In studying Hegel, Ilyenkov relied on the two-volume work of Ivan Il'in (1918). In print, of course, Ilyenkov could not cite Il'in-who had the reputation of an unbridled anticommunist and besides had besmirched himself with pro-fascist sympathies-but he included Il'in's book on the list of philosophical works that were obligatory reading alongside the works of Plato, Spinoza, the German classics, and Marx (see Ilyenkov 1997c: 237).

Long before Il'in, James Stirling ${ }^{12}$ - and then Benedetto Croce in particular-extolled the Hegelian idea of concreteness, of the "concrete universal." "And having shown that the demand of concrete knowledge is satisfied in the form of thought is [Hegel's] great merit, his immortal discovery," Croce declared in his book, Ciò che è vivo e ciò che è morto della filosofia di Hegel (1907: 206).

11 "This revolution, although it proved to be the only one at that time which the Germans could dare to do, nonetheless bore fruit that was no less valuable 'for improving the human race' than all the victories of Napoleon” (Ilyenkov 1962a: 124).

12 "The secret of Hegel," according to Stirling, was this: "Hegel [...] made $e x-$ plicit the concrete Universal that was implicit in Kant” (1865: XI). 
Hegel himself, however, first betrayed the principle of concreteness advanced by him, Croce believes. The severe criticism of panlogism-that "morbid excrescence" (l"escrescenza morbosa), devouring the flesh of history and nature, changing everything individual and empirical into raw materials for speculative construction-crowns the call in Croce to "resolve the whole philosophy into a pure philosophy of spirit (or a logicmetaphysic, as it might then have been called)" (Croce 1907: 195). ${ }^{13}$

These critical words ring fully in the spirit of Marx, who condemned Hegel for "dissolving reality into logic" and the mystification of the interrelationship of the abstract and the concrete. They are in keeping with the theses on the subject of philosophy for which Ilyenkov and Korovikov were removed from instruction in Moscow University in $1955 .{ }^{14}$ The authors of the theses insisted that it is impossible to escape "harmful Hegelianism" until philosophy imagines itself to be the science of an external world existing independently of human thought. ${ }^{15}$

Ilyenkov partly agrees with Colletti's criticism directed at Hegel: dialectical formulas must not be turned into "a priori outlines," substituting them for a concrete scientific investigation of reality. The leading lights of diamat (Ilyenkov mentions three names: Plekhanov, Stalin, and Mao Zedong) inherited this original sin of idealism from Hegel. As a consequence, Marxist philosophy degenerated into a sum of examples and syllogisms, where some "universal law of dialectics" appears in the role of a major premise, and the data of experience and the "individual" sciences appears in the role of minor premises.

Colletti's alarm is understandable-idealist dialectics is indeed fraught with such unpleasant consequences as the arrogant and scornful attitude of the intellect fascinated by it to the world of real things in general-to the world of empirically given facts, events, and phenomena. The "external world" is transformed by it into a kind of colossal reservoir of "examples" called only to "corroborate" the correctness of the dialectical theses formulated by it (Ilyenkov 1991: 123).

But to see in Hegelian logic only a complete set of outlines for all of life's occurrences, and nothing more, means sinning with the harmful Hegelianism in relation to Hegel himself.

Yes, Hegel constructs the concrete from the abstract-but any mature science does exactly the same thing, as shown in the famous Intro-

13 “...E, infine, risolvere la filosofia tutta in una pura filosofia dello spirito (o logica-metafisica, che si fosse poi voluto intitolarla)"

14 See Ilyenkov i Korovikov (2016a) as well as my review (Maidansky 2016), in which another version of these events, based on the memoirs of Teodor Oizerman, is presented.

15 See "Rekonstrukcija tezisov E. Ilyenkova i V. Korovikova” (Ilyenkov and Korovikov 2016b). 
duction to the Grundrisse. Marx declares the ascent from the abstract to the concrete to be "obviously the scientifically correct method." The mistake-Hegel's "illusion"-consisted of the given method of constructing theories being taken by him for the real process of the origin of the concrete (Marx 1986: 38). It was none other than Hegel, however, who formulated the principle of the concreteness of truth and who was able to understand the concrete as a synthesis of diversity, or "the totality of manifold determinations." ${ }^{16}$ Ilyenkov always remembered this well.

\section{III}

In his first works on Spinoza, Ilyenkov turns to the problems of the method and theory of knowledge-with an accent on the category of the abstract and of the concrete. In Spinoza's "substance" he sees above all the logical principle of "the determination of the parts on the part of the whole-or, in other terminology, the primacy of the concrete (as a 'unity of the diverse') as the initial category of Logic. In general and on the whole, this is the principle of monism. If this does not exist, then philosophy itself does not exist. Here, Hegel is right" (Ilyenkov 1997b: 180).

Ilyenkov has in mind Hegel's pithy phrase that Spinozism is the "essential commencement of all Philosophy.” (Hegel 1971: 165). ${ }^{17}$ Taking this complement at face value confuses the context, which Ilyenkov for some reason did not pay attention to. Unjustly, for the exact opposite is confirmed there: Spinoza's substance is the principle of the primacy of the abstract.

"Substance with Spinoza is not yet determined as in itself concrete," Hegel emphasizes. It is a bare, empty abstraction, "representing just what pure being (öv) was to the Eleatics," the "negation of all that is particular." and so on. Spinoza did not comprehend the principle of "concrete individuality" (fostered by Christianity) and was unable to "take into account the infinite demand of the entirely concrete" (Hegel 1994: 348).

The verdict of the Lesser Logic is even more severe: Spinoza's substance "is, as it were, a dark shapeless abyss (finstere, gestaltlose Abgrund) which engulfs all definite content as radically null" (Hegel 1974: 330).

As we see, any primacy of the concrete with a Hegelian "Spinoza" is out of the question. What is more, in Hegel's own Logic, two sterile abstractions-pure being and nothingness-take precedence. Whereas according to Spinoza, "the first principle of nature cannot [...] be conceived abstractedly or universally.” (1925b: 29) ${ }^{18}$ Nature is required to think con-

16 “Die Totalität von mannigfaltigen Bestimmtheiten” (Hegel 1969: 308).

17 “...Das Denken sich auf den Standpunkt des Spinozismus gestellt haben muß; das ist der wesentliche Anfang alles Philosophierens. Wenn man anfängt zu philosophieren, so muss man zuerst Spinozist sein.”

18 "Origo Naturae [...] nec abstracte sive universaliter concipi possit." 
cretely! Contrary to Hegel's opinion, the "Nature" of Spinoza that causes and differentiates itself has nothing in common with the indifferent abstraction of "being" in the Eleatics.

Ilyenkov does not notice the glaring inadequacy of the Hegelian portrait of Spinoza, and passes over in silence the profound difference of the (Spinozist) solution of the problem of the commencement of Logic that he himself disputes from the one proposed by Hegel.

In essence, there are two alternate logical strategies before us.

The antithesis of pure being and nothingness forms the coordinating axis of Hegelian logic. All subsequent logical categories-from the category of Becoming to the Absolute Idea-appear as mediators that unite Being and Nothingness. The concrete is the result of the mediation (Vermittelung) and the synthesis of abstractions in a concrete "organic whole."

At the base of Spinoza's logic lies the knowledge of Nature as a "most perfect Being” (Ens perfectissimum)-absolutely infinite, eternal, free, causa sui, and so on. This Nature polarizes itself on naturans and naturata, stratifies itself into infinite attributes (extensio, cogitatio, etc.), infinite modes (motus et quies, intellectus, etc.) and finite things that mutually determine each other.

Being and Nothingness do not form the abscissa and the ordinate of Spinoza's logic, as in Hegel; being in itself (in se esse) and being in another (in alio esse) do. This distinction is formed even in the first axiom of the Ethics. Spinoza's "common notion" of being differs from the category of "pure being" as much as a field differs from a pure vacuum in physics, or the universal set $(U)$ differs from the empty set $(\varnothing)$ in mathematics. These categories are polar opposites.

The selection of origin conditions all the further steps of theoretical thought. It is one thing if the initial empty abstraction is filled with concrete contents. It is another when the investigation begins with a concrete abstraction, tracing further how its potential is becoming actualized and modified.

Thus, a painter begins with a clean sheet or canvas that he covers with colors. Locke conceived of the human mind as a tabula rasa; in the future, experience would fill it with "ideas." In Aristotle, the role of tabula rasa is assigned to "prime matter" (prōto hyle); the divine Intellect introduces eidoi into it and sets it in motion. The empty space of Galileo and Newton is filled with mechanically moving bodies, and so on.

Such is the logic of impression-the imprinting of external forms into a kind of pliable substrate. Hegel hones this logic to perfection. The illusion arises in the reader of The Science of Logic that abstract being/nothing engenders all other, concrete categories from itself. What was naught, became all. A logical conjuring trick alongside which the myth of God's creation of the world from nothing pales in comparison.

On the contrary, the logic of expressions leans on the concrete subject-a substance possessing particular attributes and an internal struc- 
ture, which Spinoza names "the order and connection of things" (ordo et connexio rerum). In this context, the entirety of Spinozist philosophy is the expression of the idea of Nature. ${ }^{19}$

In the Ethics, the verb exprimo appears directly in the definition of God as a substance consisting of attributes, each of which expresses (exprimit) its essence. And further, body and mind are conceived of as two modes of expression of one and the same thing: una eademque est res sed duobus modis expressa (Ethics II, proposition 7, scholium). The splendid article by Fritz Kaufmann (1940) and the dissertation of Gilles Deleuze (2014) are dedicated to this "expressionism" of Spinoza. ${ }^{20}$

Ilyenkov characterizes the logic of Spinoza as a "method of the theoretical re-construction of a concrete whole, which-as a given concreteness - is the initial dominant" (Ilyenkov 1997b: 181). "The logic of Spinoza's thought in general is the Logic of the determination of the parts by the whole" (Ilyenkov 1997b: 174).

In parallel with Ilyenkov, Althusser attempted to interpret the logical method of Spinoza in the categories of the whole and of the part, or of the "structure" (with which the substance of Spinoza merges) and its elements, their mutual determination and "overdetermination" (surdétermination).

[I]n his effort to grasp a [...] causality, which would account for the action of the Whole on its parts, and of the parts on the Whole-an unbounded Whole, which is only the active relation between its parts: in this effort Spinoza served us, though indirectly, as a first and almost unique guide (Althusser 1976: 140-41).

Whereas, according to Spinoza, the part and the whole represent pure forms of thought, "beings of reason" (entia rationis), and not real causal relations-"consequently in Nature there are neither whole nor parts" (Spinoza 1957a: 87). Spinoza specifies especially how "sedulously we must be on our guard" against confusing the beings of reason with real beings (entia realia): “...[b]ut what is more important, since this affects so many things, is that this is the reason we often fall into great error, as has happened to many until now" (Spinoza 1957b: 270). Including, as we have seen, Ilyenkov and Althusser...

Individual things relate to God as an effect to its cause, and this relation of determination of things by God has nothing in common with the

19 In biology, the term "expression of genes" describes the process of morphogenesis, over the course of which hereditary information is realized in the molecules of a protein or RNA. Simply put, it is the process of construction of a living body in accordance with the genetic program inscribed in its initial cell.

20 See Kaufmann (1940); Deleuze (1968). 
relation of the whole to the parts. The mode is a means of action and a form of expression of the substance, and not a part of the substance.

Despite so essential an inaccuracy, Ilyenkov completely faithfully regards the Spinozist principle of the primacy of the concrete as of paramount importance. Theoretical thinking must reproduce the "order of Nature," moving from cause to effect, from concretely general substance to its particular shaping, to "individual things."

The logic of Spinoza in the history of science resists the logic of empiricism, depicting the process of thinking as the generalization of "elemental facts" encountered in sensory experience, a progress from the individual to the abstract and universal. Thus, Ilyenkov considers the work of Rudolf Carnap, The Logical Structure of the World (Logische Aufbau der Welt) to be a "formal construction of a map of the world through the logical synthesis of an unknown whole from parts, a synthesis at random without a clear idea of what 'whole' is obtained from all of this" (Ilyenkov 1997b: 181).

In Spinoza, Ilyenkov sees a powerful ally in the fight with "positivism" (in the works of Ilyenkov, all of modern empiricism is so named, wholesale), especially in those areas where direct assistance from Marx cannot be expected-at the "junctures" of logic with psychology, the physiology of higher nervous activity, and cybernetics. Together with this, the logical relationship of the teachings of Spinoza and Marx-sometimes imaginary, as we will see below-is emphasized and retouched; their cardinal differences are suppressed (and Althusser did not think it necessary to discuss these differences).

The stylization of Spinoza under Marx, along with the Hegelian "eleatization" of Spinoza, represents a clear demonstration of abstract thinking - "abstract" in the bad sense of the word, so cleverly depicted in Hegel's pamphlet Who Thinks Abstractly? ${ }^{21}$ The point is not only the nasty treatment of Spinoza's philosophy levelling its peculiarities, but that properly intelligent alternatives are lost in the solution of theoretical problems. Ilyenkov "polarized" the spectrum of their solutions-putting the question "either/or" point-blank-too often. Together with this, alongside indeterminate (on the one hand "that," on the other hand "this") and sophistic arguments, fully reasonable arguments were cut off-they were solid, concrete ones, but they were not inserted into Ilyenkov's favorite dilemma of "the materialist dialectic against the metaphysics of positivism." So it turned out in the case with Spinoza as well.

21 Ilyenkov published two very different translations of this pamphlet in 1956 and 1972. Two additional unpublished versions have been discovered in the philosopher's archive. 


\section{IV}

Ilyenkov believed the thesis on the identity of thought and being, which took on the appearance of the proposition "the order and connection of ideas is the same as the order and connection of things" 22 to be the cornerstone of Spinoza's philosophy. The "order and connection" identical for all things is the God-substance of Spinoza, in the flesh. The divine ordo et connexio shows itself in innumerable attributes, of which we people can only know two: extension and thought (in so far as we ourselves consist of their modes-body and mind).

Ilyenkov interprets extension and thought as opposites, and without a shadow of doubt ascribes that to Spinoza. Whereas the latter never even breathes a word in passing about the opposition of the attributes of substance.

Also silent on the subject is Descartes, whose "analytically strict intellect" Ilyenkov praises for the discovery of "the direct opposition" of extension and thought, of the world of ideas and "the world of things in space" (Ilyenkov 1974: 14). It is true, however, that Descartes observed that the nature of the mind and of the body "are not only different but even a certain sense contrary" (Descartes 1904: 13; 1994: 13, own emphasis added). ${ }^{23}$ The body is divisible into parts, but the mind is not: in this sole aspect they are, according to Descartes, "contrary."

In Spinoza, this opposition "in a certain sense" disappears: the indivisibility of matter, or the "extended substance" (Ethics I, proposition 15, scholium). Only its modes-bodies-are divisible, and even then, not all of them. ${ }^{24}$

The myth of the polar opposition of body and mind arises in the Platonic tradition as a philosophical sublimate of the division of labor into material and spiritual. "And that which seeks states that are the opposite of bodily states is the mind," we read in Philebus (Plato 1994: 45). Here is the origin: The "analytically strict intellect" of Descartes was late with the discovery by a good two thousand years. All that time, scholars-divided up into two camps at odds with each other-were elucidating what was more important, "more primary" in the mythical struggle of spirit and flesh...

The greatness of Spinoza lies in the fact that he was able to discard that chimera, thereby removing "the spell of Plato." Thought and matter, mind and body, are so little opposed to each other, like numbers and fig-

22 "Ordo et connexio idearum idem est ac ordo et connexio rerum" (Spinoza 1925a: 89).

23 "Eorum naturae non modo diversae, sed etiam quodammodo contrariae agnoscantur.”

24 Spinoza postulates the existence of "simple bodies" (corpora simplicissima), while Descartes believed matter was endlessly divisible. 
ures or like the spatial form of a line and its algebraic formula in Cartesian analytical geometry.

The discovery was too far ahead of its time. Even two- or three-hundred years later, the works of Spinoza were read through polarizing Platonic glasses. The neo-Kantians, positivists of all stripes, Diamat scholastics, and finally Ilyenkov-they all so firmly (and how groundlessly!) believed that Spinoza shared their conviction about the antithesis of the material and the ideal.

Lev Robinson was the first to repudiate this prejudice: "In Spinoza, as in Descartes, attributes are not conceived of as opposed and excluding each other, but as only different: sunt non opposita, sed distincta, each per se concipitur [conceived through itself]" (1913: 404-05).

Spinoza's substance represents the unity of the diverse, or the identity of the differentiated. Ilyenkov was mistaken in interpreting it as the identity of opposites. Whereas he himself, time and again, repeated the words of Spinoza: "Body and mind are one and the same thing, expressed in two different ways." It is exactly so-in two different (not opposite!) ways. Ilyenkov records a similar relationship among Truth, Good, and Beauty: they are one and the same thing expressed in three different ways. There cannot, of course be any opposition here. There are three attributes of one substance-human labor.

Any attribute of a substance, Spinoza says, is conceived per se, "through itself"; it follows that extension and thought are "conceived as really distinct-that is, one without the help of the other" (Ethics I, proposition 10). Is it possible to conceive the opposites taken separately-let us say, plus without minus, good without evil, cause without effect? No. Opposites come together, clash in contradiction, interact, and that is why they are conceived precisely as one through the other. This is the elementary truth of dialectics. So, if Spinoza writes-with geometric straightforwardness-that attributes of a substance are themselves conceived through themselves, it means that there is no opposition between them.

What was said above does not mean that Spinoza in general did not know the unity of opposites. He knew it perfectly well. It is enough to recall the category causa sui-the unity of cause and effect, or the polar determination of a single Nature: naturans and naturata. In the case with attributes, as also with its modes (body and mind), the question concerns the "really distinct," and not opposed, ways of expressing a single substance.

In the 1960s, at the same time as Ilyenkov, Louis Althusser and his galaxy of young followers (Pierre Macherey, Alexandre Matheron, Étienne Balibar, Bernard Rousset, and others) begin working on the topic of Spinoza as predecessor of Marx. Why Spinoza? For a concrete answer to this question, one had to delve deeply into the project of the structuralist reform of the dialectic. Owing to lack of space, we will limit ourselves to talking about the category of negation and its derivatives, insofar as it is 
precisely here that the confrontation of Ilyenkov and Althusser reaches maximum sharpness. Ilyenkov could in no way accept the Althusserian antithesis: the positive logic of Spinoza and Marx against the negative dialectic of Hegel.

In Althusser's opinion, "the basic structures of the Hegelian dialectic such as negation, negation of the negation, the identity of opposites, 'sublation,' the transformation of quantity into quality, contradiction and so on, have for Marx (insofar as he takes them over, and he takes over by no means all of them) a structure different from the structure they have for $\mathrm{He}$ gel" (Althusser 2005: 92). ${ }^{25}$

Negativity acquires a key meaning in Hegel's logic by virtue of the fact that any development presents itself to him as the self-alienation of the primordially simple, abstract spirit existing "in itself." At every subsequent step of development, alienation is sublated and the lost unity of spirit is restored. The cycle described repeats in spiral form until the spirit reaches totality-as "absolute spirit."

For Marx, the starting point is the concrete-as "unity in diversity" or, using Althusser's complicated terminology, "the ever-pre-givenness of some complex structured whole (le toujours-déjà-donné d"une unité complexe structurée)" (Althusser 2005: 204). As a consequence of this, Althusser asserted that the meaning of all the categories of the dialectic is changed utterly and completely, and the very terms "alienation," "sublation," and so on disappear little by little from Marx's lexicon.

He uses up masses of strength in order to explain the abundance of Hegelian terminology in the rough drafts in Capital, and also-to his great disappointment-the passage on "negation of the negation" of the forms of property in Capital itself-moreover, in the most important place where the question concerns the formation of a communist type of "individual property." 26

Althusser was carried away by the "genuine theoretical foresight" that the "shrewd philosopher" Stalin revealed in expunging the negation of the negation from the codex of laws of the materialist dialectic (for the same solution Althusser also praised Mao for). Colletti also spoke of the "dialectical games of the negation of the negation" with great disapproval.

25 In the Russian edition, in a very grammatically correct, exact translation, the author's italics are continually ignored (Althusser 2006: 135). Therefore, we have to turn to the original.

${ }_{26}$ "[C]apitalist private property [...] is the first negation of individual private property, as founded on the labor of the proprietor. But capitalist production begets, with the inexorability of a law of Nature, its own negation. It is the negation of the negation. This does not re-establish private property [...] but [...] individual property based on the acquisition of the capitalist era: i.e., co-operation and the possession in common of the land and the means of production" (Marx 1996: 750). 
On the contrary, Ilyenkov believed-as did his old comrade Mikhail Lifshitz-that the materialist dialectic was even deeper than the Hegelian dialectic, saturated with revolutionary "pathos of negation." It was not without reason that Marx condemned Hegel for "uncritical positivism," the consequence of which is the "restoration of the existing empirical world": the philosophical apologia of existing-frequently reactionaryregimes and institutions.

With complete persistence, Ilyenkov and Lifshitz drew a distinction between concrete and abstract negation, and "sublating" and destructive, "futile" negation (Lenin). ${ }^{27}$ Thus, Ilyenkov wrote, real negation of private property is not reduced to its "formal, legal negation"-that is, to the transfer of property to the command of the State-but requires "the actual assimilation by each individual of all wealth accumulated within the limits of "private property" (i.e., "alienated from him")" (Ilyenkov 1988: 106). The very essence of Marx's communism appears to Ilyenkov in this.

Without such categories as "alienation" and "sublation," it is impossible to understand the historical process of the affirmation and "selfnegation" of private property. In one place in his report for the "Marx and the Western World" symposium, it appears that Ilyenkov polemicizes with the Althusserian conception of the "epistemological break" in the works of Marx:

Undoubtedly, the mature Marx uses the term "alienation" (Entfremdung) more carefully (and more strictly), differentiating this concept from "objectification," "concretization," and similar concepts in the strictest fashion. But for me it is equally indubitable that the whole practical problem of the earlier works is fully reproduced here-indeed, in an advanced terminological form (Ilyenkov 1988: 107).

Sublation (Aufhebung) is one of Marx's favorite categories, encountered hundreds of times in his works-including the very last. It is the highest logical and historical form of the resolution of contradictions. For Ilyenkov, the difference between the dialectical methods of Hegel and of Marx lies in where the key to the "lock" of contradictions should be sought-in the structures of pure thought or in a series of historical facts. The distinguishing feature of Marx's materialist method of the sublation of contradictions is the principle of concrete historicism.

The Althusserians contrasted the particular "positivity" of Spinoza with the "negativity" of Hegel. Under their pens, Spinoza becomes similar

27 "Not empty negation, not futile negation, not sceptical negation, vacillation and doubt is characteristic and essential in dialectics - which undoubtedly contains the element of negation and indeed as its most important element-no, but negation as a moment of connection, as a moment of development, retaining the positive..." (Lenin 1973: 207). 
to "his godly kinsman Jesus Christ" (Heinrich Heine), accepting everything existing as good, saying "yes" to everyone and "no" to no one.

It is curious, that this image prompted them... Hegel, noting time and again the deficit of negativity in Spinoza's philosophy: "The negation of negation is, however, contradiction [...] and this contradiction, which is typical for reason (das vernünftige ist), is lacking in the case of Spinoza." As a consequence, the "principle of subjectivity is removed" in him (Hegel 1994: 370).

To structuralist ears, these reproaches sound like praise. He negated contradictions? Genius! He removed subjectivity? So be it. The subject is dead, long live the structure!

However, one serious discordance was found: "Spinoza has set up the great proposition, all determination implies negation” (Hegel 1994: 369). Does this mean, after all, that without negation there is no making do? At least, when the question concerns finite things. Hegel chose an extraordinarily simple exit from the position: in Spinoza's eyes, finite things as such are insignificant and illusory. Spinozism is the negation of true existence of finite things-“acosmism." 28

On this point, Deleuze extends the hand of agreement to Hegel, but again changing minus to plus:

In the reproach that Hegel will make to Spinoza, that he ignored the negative and its power, lies the glory and innocence of Spinoza, his own discovery. In a world consumed by the negative, he has enough confidence in life, in the power of life, to challenge death, the murderous appetite of men, the rules of good and evil, of the just and the unjust. Enough confidence in life in order to denounce all the phantoms of the negative (Deleuze 1981: 22).

Or, to resume: "Spinoza's philosophy is a philosophy of pure affirmation" (Deleuze 2014: 43). The Marxists of the Althusserian temper gladly sided with Deleuze: "Spinoza's thought [...] does not know the negative" (Antonio Negri 1981: 248).

In fact, the "negative" is absent in Spinoza only in the sphere of the infinite-of Substance with its attributes and infinite modes. There is no passing to finite modes and "singular things" (res singulares) without "negation." Spinoza's category of determination precisely expresses this logical transition from the infinite to the finite.

28 "Spinoza maintains that there is no such thing as what is known as the world; it is merely a form of God, and in and for itself it is nothing. The world has no true reality, and all this that we know as the world has been cast [by Spinoza] into the abyss of the one identity" (Hegel 1994: 366). 
God determines all things for existence and for action, ${ }^{29}$ and determination is negation. We now have the "negative," emanating from God himself. That means the negative is not a "phantom" at all. Negation is an aspect of the real, causal relationship of God to singular things. It goes without saying that the "divine" act of determination-the self-expression of the infinite in the finite-can in no way be a sheer negation. Determination affirms in negating, it engenders things, at the same time establishing the limits of its existence and limiting its actions through "the power of external causes." This, strictly speaking, is the same positive negation-"sublation"-that Hegel and Althusser with his associates flatly took no notice of in the Ethics.

There is no space here to investigate in more detail Spinoza's dialectic of the infinite and the finite, of affirmation and negation, and of positive affects and "passions." It is clear only that Ilyenkov's image of Spinoza as a dialectician is much closer to the original than the one-sided "positive" image from Deleuze-even while in his Dialectical Logic, Ilyenkov interprets Spinoza's concept of thought in a crudely materialistic manner. ${ }^{30}$

\section{V}

What is the difference in the philosophies of Spinoza and Marx? In the response to that question it is possible to clearly see the specific character of the Ilyenkov triangle, and, in general, the difference of his dialectical logic from all other branches on the tree of Marxist philosophy.

Spinoza believed thinking-the "intellect"-to be an innate human ability, while Marx saw the origin of human thought in labor, in the objectively practical transformation of nature.

According to Marx, only a nature reaching the stage of humans socially producing their own lives-a nature changing and realizing itself in the person of humanity-inherently thinks [...] Labor-the process of altering nature through the activities of social humanity-is the "subject" to which "thinking” belongs as a "predicate" (Ilyenkov 1974: 54).

Spinoza comes closer than any of the philosophers before Marx to this "practical materialist" view of thought. Ilyenkov extensively quotes the place in De intellectus emendatione where a direct analogue is drawn between thought and labor.

29 "Res, quae ad aliquid operandum determinata est, a Deo necessario sic fuit determinata” (Spinoza 1925a: 68).

30 I have written further on this in Maidansky (2002, 2009). 
As with labor thinking is required in tools, Spinoza notes. He compares the activity of the intellect with the forging of iron using a hammer, explaining that the quality of our "intellectual work" depends explicitly on the perfection of the tools. Humanity is given "intellectual tools" (instrumenta intellectualia) from nature, and with the help of these innate tools we carry out at first "the simplest tasks," using ideas forged by them as tools for more complex work, "and thus by degrees advances, until it reaches the pinnacle of wisdom" (Spinoza 1957c: 329).

This "blacksmith" analogy is much deeper and closer to the truth than Leibniz's naturalistic comparison of innate ideas in the soul with the veins in marble. Ilyenkov comments:

What Spinoza did not understand is thus that the initial, imperfect "intellectual tools" are the products of material labor, and not the products of nature. He considers them to be the products of nature. And in thisin nothing else-lies the weakness of his position. But he shares this weakness even with Feuerbach. In no way should this shortcoming be called idealistic vacillations. It is simply an organic shortcoming of all old materialism (Ilyenkov 1962b: 184).

The first of the philosophers to "grasp" (faßt) the "essence of labor" is Hegel; the greatness of his Phenomenology of Mind consists of the fact that man is for the first time understood "as the outcome of man's own labor," Marx wrote (1975: 330). From Spinoza, Marx inherits the concept of Nature as the cause of itself and the substance of everything on earth, including human labor. We note in particular that Ilyenkov saw a radical atheist-a "theomachist"-in Spinoza, and he explained the use of the word "God" as Spinoza's attempt to speak with his contemporaries in a language intelligible to them. ${ }^{31}$ There actually is a weighty foundation for such an explanation. The first "rule of life" in De intellectus emendatione teaches accommodation to the language of the crowd, yielding to its ordinary understanding as much as possible, provided it does not stand in the way of the higher goal of human existence. This rule, indisputably, concerned the word "God." And of course, the philosopher could not leave the "vulgar," religious sense of this word unchanged.

Over the course of his entire life, Marx wrote about Nature in a completely Spinozist key. In labor, he saw "only the expression of a natural power, human labor power” (Marx 1961: 13). The works of human hands and thought are the works of Nature itself, having assumed the shape of a human being and transforming itself. Spinoza would certainly have gladly subscribed to the following words: "That man's physical and spiritual life is linked to nature means simply that nature is linked to itself, for man is

31 See Vasil'ev and Naumenko (1977: 64). 
a part of nature" (Marx 1975: 275). "Man is directly a natural being” (Marx 1975: 333). "[T]he working subject is a natural individual, a natural being (natürliches Dasein) [...] [h] himself is not only the organic body, but also this inorganic nature as a subject” (Marx 1986: 412).

The level of the historical development of humanity is defined by the extent to which it has been able to master nature (both the external and physical as well as its own, the social) through labor and to absorb into itself the diversity of the worlds and the forces of nature. In human society, the young Marx sees the logical completion of the history of natureits new, highest turn: "the true resurrection of nature-the realized naturalism of man and the realized humanism of nature" (Marx 1974: 538). ${ }^{32}$ These words are recalled by a powerful echo in Cosmology of the Mind, where Ilyenkov begins to prove that the existence of humanity is the necessary condition for the resurrection of the Universe...

Among Marxists, Ilyenkov has proven to be nearly the only one who took up and developed the Spinozist theme of Nature as the substancesubject of human existence. In Soviet diamat, nature is usually understood in the spirit of the French Enlighteners-as an external medium and the material of human activity. On the other hand, Lukács relativized the concept of nature: "Nature is a social category [...] Nature's form, its content, its range and its objectivity are all socially conditioned (Ilyenkov 2006: 105).

If Spinoza's Nature-substance is mentioned, it is only in the context of criticism of this metaphysical abstraction in The Holy Family. Thus, in Alfred Schmidt's dissertation The Concept of Nature in Marx, written in the late 1950s under the guidance of Horkheimer and Adorno, we read: "In attacking Spinoza's concept of Substance, he [Marx] attacked the notion that nature exists 'in itself' without human mediation" (Schmidt 1971: 31). And Althusserian "substance," interpreted as a pseudonym for "structure," is worlds apart from Spinoza's "naturing Nature" (Natura naturans).

Lenin's "matter," defined as "objective reality given to us in sensations," is also foreign to the spirit of Spinoza. His Nature is grasped exclusively by reason, by "intellect." Only certain modes of substance are accessible to the senses, although these are experienced by us in a confused and inadequate form...

In his liking for Spinoza, Ilyenkov goes so far as to depict the author of the Ethics as the ideologue of the proletariat. ${ }^{33}$ Despite the fact that the concept of labor is still absent in Spinoza, and in investigating social life he completely abstracts from the class differences of people-even the obvious ones under which Plato reflected in his Republic. Spinoza takes

32 "Also die Gesellschaft ist die vollendete Wesenseinheit des Menschen mit der Natur, die wahre Resurrektion der Natur, der durchgeführte Naturalismus des Menschen und der durchgeführte Humanismus der Natur.”

33 See Ilyenkov (1977: 46). 
into consideration only two differences in human communities: (i) the rulers and the people, (ii) the "crowd" and the "philosophers." Those who live by passion and not by intellect are numbered among the "crowd" (plebs, vulgus), with no differentiation between proletariat and bourgeois. All class indications are completely dissolved into Spinoza's conception of the "multitude" (multitudo), so beloved of modern neo-Marxists, following Antonio Negri’s example. ${ }^{34}$

In general, Spinoza is furthest of all from Marx in a theory of social life: the former looks at society with the eyes of a psychologist, the latter with the eyes of an economist. For Spinoza, social life shows the battle of affects; for Marx, it is the struggle of classes. Ilyenkov did not attempt to "reconcile" their views of society, and was silent about the differences.

Althusser saw in Spinoza a critic of "ideology" à la Marx. Recently, voices have been heard trying to convince us that in the field of political economy, "Spinoza can now help us supplement Marx" (Lordon 2010: 10). ${ }^{35}$ Ilyenkov did not go that far, but he saw in Spinoza his own contemporary and protested against the treatment of Spinozism as a completed, though high, stage of the development of philosophical thought.

Spinoza, they say, did his job well, and may rest in peace in his grave. And we, they say, will bring flowers of appreciation to it [...] It seems to me that this manner of treating his memory is the most mistaken, and the most murderous for the philosophy of Spinoza-the worst means of violence against him [...] The task that I risked placing before myself is to expound and throw light on Spinoza's [philosophy] so that the generalized algebraic-that is, the general logical-exit from the present difficulties would be seen by the economist, the psychologist, the researcher of higher neurological activity-to say nothing of the logician, the philosopher occupying himself with the so-called "epistemology," the "theory of knowledge" (Ilyenkov 1997b: 171).

Reflecting on the problems of contemporary psychology and pedagogy, Ilyenkov-as Lev Vygotsky did in his time-repeatedly appealed to Spinoza.

Ilyenkov's philosophical triangle is not simply a historical philosophical construction, but a kind of "logical compass"-a method that allows orientation in the world of "great" science-defining the direction of the solution of fundamental scientific problems. Unfortunately, in the

34 They interpret the "multitude" as a global community of individualities, "singularities," consolidating into a global (radically decentralized and democratic in its nature) "biopolitical network" with which Antonio Negri and Michael Hardt link their hopes for the coming communist revolution (2004).

35 "Le paradoxe temporel étant que si Marx est postérieur à Spinoza, ça n’en est pas moins Spinoza qui pourrait maintenant nous aider à compléter Marx.” 
Soviet Union, no scholars who wished to or were able to "think in Spinoza" ${ }^{36}$ were to be found after Ilyenkov.

$$
* * *
$$

Casting a final glance at "Ilyenkov's triangle," we turn our attention to the inequality of two of its sides: if Hegel is subject to impartial criticism-"turned on his head," according to Marx's behest-then only a couple of shortcomings are noted in Spinoza, and Ilyenkov finds weighty historical excuses for them. In the Ethics, a complete collection of Marxist virtues is discovered: not only materialism with the dialectic, but also a moral code for working people. ${ }^{37}$

A strongly pronounced antimetaphysical attitude is common to Ilyenkov and West European Marxism: philosophy does not have the right to lay claim to the role of a "scientific world outlook," let alone instruct scientists on how "the world as a whole" is structured. The Diamat scholastics, who stamped Hegel with idealism, shared this metaphysical claim with him. And they accused Ilyenkov of "harmful Hegelianism."

The turn to Spinoza occurred in Ilyenkov and Althusser practically simultaneously. Both Marxists attempted to maximally bring Spinoza and Marx together, paying little attention to the differences of their philosophical "optics" and ignoring Marx's critical darts addressed to Spinoza's concept of substance and his metaphysics in general. These were rather variations on Spinoza's theme, not particularly troubled about historical and philosophical adequacy.

A more intense gaze reveals the principal divergences between Ilyenkov and leading Western Marxists in the understanding of both Hegel and Spinoza. This concerns above all the attitude towards a contradiction and towards the methods of its solution (sublation, "negation of the negation"). Ilyenkov's dialectical logic never joined the "trends" of the evolution of Western Marxism-which, however, does not diminish its theoretical force and depth.

Translated from the Russian by Jeff Skinner

36 The title of an article about Gilles Deleuze by Pierre Machery (1988).

37 The philosophy of Spinoza "is the natural theoretical position of a humanity that knows how to and loves to make clever, useful things for other people with its own hands, not with the hands of others [...] Therefore the Ethics [...] could become a real code of moral axiomatics of the better part of a society born in torment-its labouring part, its working estate-and in no way of the part (class) of businessmen, tradesmen, and bankers" (Ilyenkov 1977: 46). 


\section{Andrey Maidansky}

\section{Bibliography}

Althusser, Louis (1969). Lire le Capital, Vol. 2. Paris: Maspero.

Althusser, Louis (1976). Essays in Self-Criticism. London: NLB.

Althusser, Louis (2005). Pour Marx. Avant-propos de Etienne Balibar. Paris: Éditions La Découverte.

Colletti, Lucio (1961). “Prefazione.” In La dialettica dell'astratto e del concreto nel Capitale di Marx, by Evald Ilyenkov. Trans. Vittorio Strada and Alberto Sandretti, VILIX. Milan: Feltrinelli.

Croce, Benedetto (1907). Ciò che è vivo e ciò che è morto della filosofia di Hegel. Bari: Laterza \& Figli.

Deleuze, Gilles (1968). Spinoza et le problème de l'expression. Paris: Éditions de Minuit.

Deleuze, Gilles (1981). Spinoza: philosophie pratique. Paris: Éditions ode Minuit.

Deleuze, Gilles (2014). Spinoza i problema vyrazhenija [Spinoza and the problem of expression]. Moscow: Institut obshchegumanitarnykh issledovanij.

Della Volpe, Galvano (1950). Logica come scienza positiva. Messina: D’Anna.

Della Volpe, Galvano (1969). Logica come scienza storica. Rome: Riuniti.

Descartes, René (1904). “Meditationes de prima philosophia.” In EEuvres de Descartes, Vol. 7, 1-90, Paris: Cerf.

Descartes, Rene (1994). "Razmyshlenija o pervoj filosofii” [Meditations on the first philosophy]. In Sochinenija [Compositions], Vol. 2, 3-72. Moscow: Mysl’.

Engels, Friedrich (1987). Marx \& Engels Collected Works, Vol. 25: Engels. London: Lawrence \& Wishart.

Engels, Friedrich (1990). Marx \& Engels Collected Works, Vol 26: Engels, 1882-89. London: Lawrence \& Wishart.

Hardt, Michael, and Antonio Negri (2004). Multitude. War and Democracy in the Age of Empire. London: The Penguin Press.

Hegel, Georg Wilhelm Friedrich (1969-71). Werke in 20 Bänden. Frankfurt am Main: Suhrkamp.

Hegel, Georg Wilhelm Friedrich (1969). “Wissenschaft der logik II.” In Werke, Bd. 6. Frankfurt am Main: Suhrkamp.

Hegel, Georg Wilhelm Friedrich (1971). "Vorlesungen über die geschichte der philosophie, III.” In Werke, Bd. 20. Frankfurt am Main: Suhrkamp.

Hegel, Georg Wilhelm Friedrich (1974). Ehnciklopedija filosofskikh nauk [The encyclopedia of the philosophical sciences in outline], Vol. 1. Moscow: Mysl'.

Hegel, Georg Wilhelm Friedrich (1994). Lekcii po istorii filosofii [Lectures on the history of philosophy], Vol. 3. Saint Petersburg: Nauka.

Ilyenkov, Evald (1960). Dialektika abstraktnogo i konkretnogo v "Kapitale" K. Marksa [The dialectics of the abstract and the concrete in Marx’s Capital]. Moscow: Izdatel'stvo Akademii nauk SSSR.

Ilyenkov, Evald (1962a). "Problema ideala v filosofii” [Problem of the ideal in philosophy]. Voprosy filosofii [Questions of philosophy] 10: 118-29.

Ilyenkov, Evald (1962b). "Ponimanie abstraktnogo i konkretnogo v dialektike i formal'noj logike" [The understanding of the abstract and the concrete in dialec- 


\section{The Ilyenkov Triangle: Marxism in Search of its Philosophical Roots}

tics and in formal logic]. In Dialektika i logika. Formy myshlenija [Dialectics and logic. Forms of thinking], 172-210. Moscow: Izdatel'stvo Akademii nauk SSSR. Ilyenkov, Evald (1974). Dialekticheskaja logika [Dialectical logic]. Moskva: Politizdat. Ilyenkov, Evald (1977). “Operedivshij svoe vremja” [One who outstripped his time]. Kur'er UNESCO, July: 45-7.

Ilyenkov, Evald (1988). "Marks i zapadnyj mir” [Marx and the western world]. Voprosy filosofii [Questions of philosophy] 10: 98-112.

Ilyenkov, Evald (1991). “Vershina, konec i novaja zhizn' dialektiki (Gegel' i konec staroj filosofii)" [The peak, the end and the new life of dialectics (Hegel and the end of the old philosophy] In Filosofija i kul'tura [Philosophy and culture], 115-41. Moscow: Politizdat.

Ilyenkov, Evald (1997a). Dialektika abstraktnogo i konkretnogo v nauchno-teoreticheskom myshlenii [The dialectics of the abstract and the concrete in scientific theoretical thought]. Moscow: ROSSPEN.

Ilyenkov, Evald (1997b). "K dokladu o Spinoze" [Concerning the lecture on spinoza]. In Drama sovetskoj filosofii: Evald Vasil'evich Ilyenkov [The drama of Soviet philosophy: Evald Valsilevich Ilyenkov], 170-82. Moscow: IFRAN.

Ilyenkov, Evald (1997c). "Spisok literatury dlja filosofskogo samoobrazovanija, prodiktovannyj E.V. Ilyenkovym studentu filosofskogo fakul'teta MGU Shulevskomu N.B." [The list of works for the philosophical self-education which Ilyenkov dictated to the student of the Philosophy Faculty of Moscow University N.B. Shulevsky] In Drama sovetskoi filosofii: Evald Vasil'evich Ilyenkov [The drama of Soviet philosophy: Evald Valsilevich Ilyenkov], 237. Moscow: IFRAN.

Ilyenkov, Evald (2016). "Filosofskaja tetrad'” [Philosophical notebook]. In Strasti po tezisam o predmete filosofii (1954-1955) [Passions around the theses on the subject of philosophy (1954-1955)], 169-227. Moscow: Kanon+.

Ilyenkov, Evald, and Valentin Korovikov (2016a). Strasti po tezisam o predmete filosofii (1954-1955) [Passions around the theses on the subject of philosophy (19541955)]. Moscow: Kanon+.

Ilyenkov, Evald, and Valentin Korovikov (2016b). "Rekonstrukcija tezisov E. Ilyenkova i V. Korovikova” [Theses of Ilyenkov-Korovikov Reconstructed]. In Strasti po tezisam o predmete filosofii (1954-1955) [Passions around the theses on the subject of philosophy (1954-1955)], 143-47. Moscow: Kanon+.

Il'in, Ivan (1918). Filosofiia Gegelia kak uchenie o konkretnosti Boga i cheloveka [The philosophy of Hegel as a doctrine of the concreteness of God and humanity], 2 Vols. Moscow: Izdatel'stvo Lemana i Sakharova.

Kaufmann, Fritz (1940). “Spinoza's System as Theory of Expression.” Philosophy and Phenomenological Research 1.1: 83-97.

Lenin, Vladimir (1973). "Filosofskie tetradi" [Philosophical notebooks]. In Polnoe sobranie sochinenii [Complete works], 5th ed., Vol. 29. Moscow: Politizdat.

Lordon, Frédéric (2010). Capitalisme, désir et servitude: Marx et Spinoza. Paris: La Fabrique.

Lukács, György (2006). “Izmenenie funkcij istoricheskogo materializma” [Revising the function of historical materialism]. In Politicheskie teksty [Political texts], 88-134. Moscow: Tri kvadrata. 


\section{Andrey Maidansky}

Macherey, Pierre (1988). “Penser dans Spinoza.” Magazine Littéraire 257: 40-43.

Maidansky, Andrey (2002). "Poniatie myshleniia u Il'enkova i Spinozy” [The Concept of Thought in Ilyenkov and Spinoza]. Voprosy filosofii [Questions of philosophy] 8: 163-73.

Maidansky, Andrey (2009). “Kak razlagalas' mysl” [How the thought decayed]. Logos 1: 175-83.

Maidansky, Andrey (2012). “Predislovie” [Foreward]. In Benedikt Spinoza--pro et contra: lichnost' i tvorchestvo B. Spinozy $v$ otsenkakh russkikh myslitelei i issledovatelei: antologiia [Benedict Spinoza-pro et contra: the personality and creativity of B. Spinoza in an appraisal of Russian thinkers and researchers: anthology], 7-45, St Petersburg: Izdatel'stvo RKhGA.

Maidansky, Andrey (2016). “Drama rozhdeniia filosofskoi mysli: delo Ilyenkova-Korovikova" [The drama of the birth of philosophical thought: The case of IlyenkovKorovikov]. Svobodnaia mysl' [Free thought] 2: 213-21.

Marx, Karl (1961). “Kritika Gotskoi programmy” [Critique of the Gotha programme]. In Sochineniia, vol. 19.

Marx, Karl (1975). Marx \& Engels Collected Works, Vol. 3 [March 1843-August 1844]. London: Lawrence \& Wishart.

Marx, Karl (1976), Marx \& Engels Collected Works, Vol. 6: Marx and Engels, 1845-48. London: Lawrence \& Wishart.

Marx, Karl (1983), Marx \& Engels Collected Works, Vol. 40: Letters, 1856-59. London: Lawrence \& Wishart.

Marx, Karl (1986). Marx \& Engels Collected Works, Vol. 28: Marx, 1857-61. London: Lawrence \& Wishart.

Marx, Karl (1987). Marx \& Engels Collected Works, Vol. 29: Marx, 1857-61. London: Lawrence \& Wishart.

Marx, Karl (1996). Marx \& Engels Collected Works, Vol. 35: Capital, Volume 1. London: Lawrence \& Wishart

Marx, Karl, and Friedrich Engels (1956-90). Werke in 43 Bänden. Berlin: Dietz Verlag.

Marx, Karl, and Friedrich Engels (1975). Marx \& Engels Collected Works, Vol. 4: Marx and Engels, 1844-45. London: Lawrence \& Wishart.

Marx, Karl, and Friedrich Engels (1976). Marx \& Engels Collected Works, Vol. 5: Marx and Engels, 1845-47. London: Lawrence \& Wishart.

Negri, Antonio (1981). L'anomalia selvaggia. Saggio su potere e potenza in Baruch Spinoza. Milano: Feltrinelli.

Plato (1994). “Philebus.” In Sobranie sochinenij [Collected works], vol. 3. Moscow: Mysl'. Plekhanov, Georgi (1928). "Filosofskaia ehvoluciia Marksa” [The philosophical evolution of Marx] In Sochinenija [Compositions], Vol. 18, 323-34. Moscow-Leningrad: Gosizdat.

Plekhanov, Georgi (1956). “Bernstein i materializm” [Bernstein and materialism]. In Izbrannye filosofskie proizvedeniia [Selected philosophical works], Vol. 2, 346-61. Moscow: Gosudarstvennoe izdatel'stvo politicheskoi literatury.

Robinson, Lev (1913). Metafizika Spinozy [Spinoza's metaphysics]. St Petersburg: Shipovnik. 
Schmidt, Alfred (1971). The Concept of Nature in Marx. London: NLB.

Spinoza, Benedict (1925). Opera. 4 Vols. Heidelberg: Carl Winters Universitätsbuchhandlung.

Spinoza, Benedict (1925a). "Ethica ordine geometrico demonstrata.” In Opera, Vol. 2, 41-308. Heidelberg: Carl Winters Universitätsbuchhandlung.

Spinoza, Benedict (1925b). “Tractatus de intellectus emendatione.” In Opera, Vol. 2, 1-40. Heidelberg: Carl Winters Universitätsbuchhandlung.

Spinoza, Benedict (1957). Izbrannye proizvedeniia [Selected works], 2 Vols. Moscow: Gospolitizdat.

Spinoza, Benedict (1957a). "Kratkii traktat o boge, cheloveke i ego schast'e” [Short treatise on God, man, and His well-being]. In Izbrannye proizvedenija [Selected works], Vol. 1, 67-171. Moscow: Gospolitizdat.

Spinoza, Benedict (1957b). "Prilozhenie, soderzhashchee metafizicheskie mysli" [Appendix containing metaphysical thoughts]. In Izbrannye proizvedenija [Selected works], Vol. 1, 265-315. Moscow: Gospolitizdat.

Spinoza, Benedict (1957c). “Traktat ob usovershenstvovanii razuma” [Treatise on the emendation of the intellect] In Izbrannye proizvedenija [Selected works], Vol. 1, 320-58. Moscow: Gospolitizdat.

Stern, Jacob (1897). "Der ökonomische und der naturphilosophische Materialismus." Die Neue Zeit 36: 301-4.

Stirling, James Hutchinson (1865). The Secret of Hegel: Being the Hegelian System in Origin, Principle, Form, and Matter, Vol. 1. London: Longman.

Vasil'ev, I. [pseudonym of Ilyenkov] and Naumenko, Lev (1977). “Tri veka bessmertiia” [Three centuries of immortality]. Kommunist 5: 63-73. 